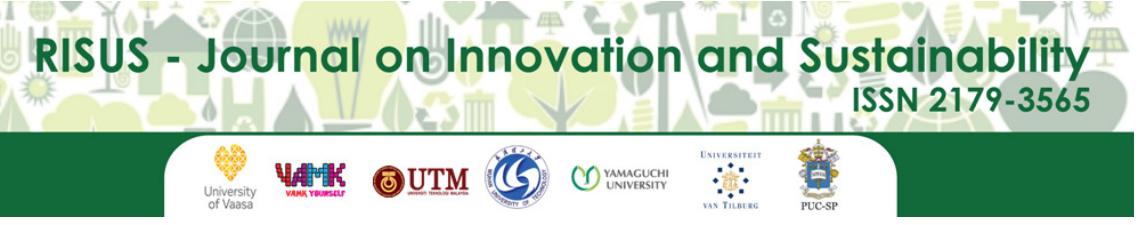

RISUS - Journal on Innovation and Sustainability volume 10, número 1 - 2019

ISSN: 2179-3565

Editor Científico: Arnoldo José de Hoyos Guevara Editora Assistente: Lívia Lopes Aguiar Avaliação: Melhores práticas editoriais da ANPAD

\title{
BIODIVERSITY IN IBERO AMERICAN COUNTRIES: OVERVIEW ABOUT THE NATURAL AND SOCIAL
}

\author{
Biodiversidade nos países Iberoamericanos: \\ Visão geral sobre a natureza e o social
}

\begin{abstract}
Tatiana Almendra Dutra, Marcos Ferreira, Fábia de Mattos Spadoto, Arnoldo Jose de Hoyos Guevara School of Management, Pontifical Catholic University of Sao Paulo, Sao Paulo, Brazil arnoldodehoyos@yahoo.com.br
\end{abstract} E-mail: tadutra@hotmail.com,marcos.ferreira@outlook.com, fabia_spadoto@hotmail.com,

\begin{abstract}
Authors such as Brown (2009) and Sachs (2010) have been discussing the importance of biodiversity and the need to build a harmonious relationship between social capital, natural and economic. Thus, the aim of this study is to make an analysis of the Ibero-American region (AIBER), in which concentrate the greatest biodiversity on the planet. The 21 countries of the Ibero-American region were grouped using an analysis of variables with high explanatory power by principal component analysis. We conclude that there is an imbalance between the variables, noting a preponderance of the capital to the detriment of natural capital.
\end{abstract} Key words: Biodiversity, Social, Ibero-American. 


\section{RISUS - Journal on Innovation and SUstainability ISSN 2179-3565 \\ (1) nomacoun

\section{BIODIVERSITY IN IBERO AMERICAN COUNTRIES: OVERVIEW ABOUT THE NATURAL AND SOCIAL}

Biodiversidade nos países Iberoamericanos: Visão geral sobre a natureza e o social

Tatiana Almendra Dutra, Marcos Ferreira, Fábia de Mattos Spadoto, Arnoldo Jose de Hoyos Guevara School of Management, Pontifical Catholic University of Sao Paulo, Sao Paulo, Brazil E-mail: tadutra@hotmail.com, marcos.ferreira@outlook.com,fabia_spadoto@hotmail.com, arnoldodehoyos@yahoo.com.br

Resumo: Autores como Brown (2009) e Sachs (2010) vêm discutindo a importância da biodiversidade e a necessidade de construir uma relação harmoniosa entre o capital social, o natural e o econômico. Nesse contexto o objetivo deste estudo é fazer uma análise da região Iberoamericana (AIBER), na qual se concentra a maior biodiversidade do planeta. Os 21 países da região foram agrupados usando uma análise de variáveis com maior poder explicativo pela análise de componentes principais, mostrando que existe uma preponderância nos agrupamentos no referente ao capital social do que em relação ao capital natural, reforçando as ideias de Maslow (1975) e Barret (2006).

Palavras-Chave: Biodiversidade, Capital Social, Iberoamerica

RECEBIDO EM: 21/02/2019

ACEITO EM: 01/03/2019 


\section{INTRODUCTION}

Many authors have discussed the importance of biodiversity for human well-being and the need to work it. Moreover, these questions have to work with a harmonious relationship between natural capital, social and economic as well. Scharmer et al. (2014) discusses the passage of a self-centered awareness for an ecocentric consciousness, especially regarding the organizational and social leaders in which this harmony is increasingly present. Thinking about it the aim of this paper that it is to analyze the countries of the Ibero-American region (AIBER). These countries concentrate the greatest biodiversity on the planet, namely Natural Capital and Social. Additionally, the purpose to this research was verifying the degree of relationship between the variables of interest.

The data offered by the Ibero-American Millennium Project - RIBER aims to: promote the study of foresight in Latin America through a community with skills, concepts, methods and prospective practices for analyzing and exchanging information about the different countries. These study also contribute to the collective learning of regional actors to develop skills in prospective, providing references of best practices in the region and the world as a whole.

The sample of study were the 21 Ibero-American, six are among the 17 top most mega-diverse countries, with $70 \%$ of the planet's biodiversity are: Brazil, Colombia, Ecuador, Mexico, Peru and Venezuela. Brazil is considered the country with the greatest biodiversity in flora and fauna with 15 to $20 \%$ of the biodiversity of the planet, so it can be said that the greatest biodiversity is concentrated in Latin American countries (MARQUES, 2014).

\section{THEORETICAL FRAMEWORK}

Bloch (2005) states that biodiversity is the result of a process that began 3.5 million years ago, at the time that complex molecules began to multiply in the waters of the primordial sea. On the other hand, Franco (2013) based on Wilson (1997); Meime, Soule and Noss (2006), Sarkar (2002) and Lewis (2007) mention that the concept of biodiversity is a recent phenomenon that was set during the forum planning on Biological Diversity, National Forum on Biodiversity, held in Washington, 21 the September 24, 1986 by Walter G. Rosen in 1985, came the Society for Conservation Biology (SCB) and in 1987 published the first Conservation Biology journal issue, which has become the main vehicle for scientific communication on biodiversity.

According to the Convention on Biological Diversity - CBD (2000), biodiversity can be understood as the variety among living organisms from all sources including, inter alia, terrestrial, marine and other aquatic ecosystems and the ecological complexes of which they are part; this includes diversity within species, between species and ecosystems. Schaller (2007 apud Franco, 2013) points out that when the subject biodiversity emerged, It was associated with the preservation of species and their habitat, however, the author also said that these issues are directly related to natural, social and economic issues.

Guide Sustainable Public Management (GPS, 2014) brings the idea that is placed to the maintenance and preservation of biodiversity is settled by capital that group together, developing networks and rules governing properly actions or events affecting biodiversity; The market is a shortsighted and invisible nature of both the social, as the green (Sachs, 2010).

Sachs (2010) believes that the relationship between society and nature promotes efforts to: the social is in charge, while the ecological assumed restraint and economic reattached in its instrumental role (GUIA GPS, 2014). Brown (2009) proposes, from his book "Plan B 4.0", a global mobilization to save our civilization building a global economy to able to sustain economic progress and the creation of an honest market. It based on three interdependent goals: to stabilize climate and population eradicate poverty and restore natural stands of nature, such as water, soil and air. According to the author it is necessary to restructure the tax system by reducing taxes on labor and increasing on carbon emissions and other environmentally destructive activities.

To understand the relationship between social and environmental is necessary to understand Maslow's theory, she in that behavior is motivated by basic needs based on two groups: (1) deficiency, which are the needs: physiological, safety, love and esteem; and (2) growth, which are needs related to self-development and self-fulfillment of human beings. With that he tried to comprehend and explain what energizes, directs and sustains human behavior. 
Maslow (1975) can only move from one level to another if that level is minimally satisfied, that is, when unsatisfied physiological needs of the individual organism is fully focused to meet them being unable to think of other needs. For example, a hungry person think about meeting their security needs is impossible, but as soon as satisfied minimally seeks to meet the need for security, then emotionalsocial, then self-esteem and last the need located at the top of the pyramid requires full satisfaction, it is the self-realization related to the need of every human being to grow and fully realize their potential.

Thereafter, Maslow added to his theory, the desire of every human being to know and understand and help others realize their potential. Demonstrating a natural human need to seek the meaning of things in order to organize the world in which they live. They are called cognitive needs and include the desire to know and to understand, organize, organize, analyze and seek relationships and meanings.

From needs as described by Maslow, Barrett (2006) developed a model with seven levels of consciousness to measure the values of an organization / company. According to the author the companies and firms with more self-performance are those that establish and preserve a worshiper guided by shared values, which all seek the same future vision, personal fulfillment and meet their physical, emotional, mental and spiritual needs. Barrett (2006) reveals seven levels of personal and social consciousness described in Figure 1.

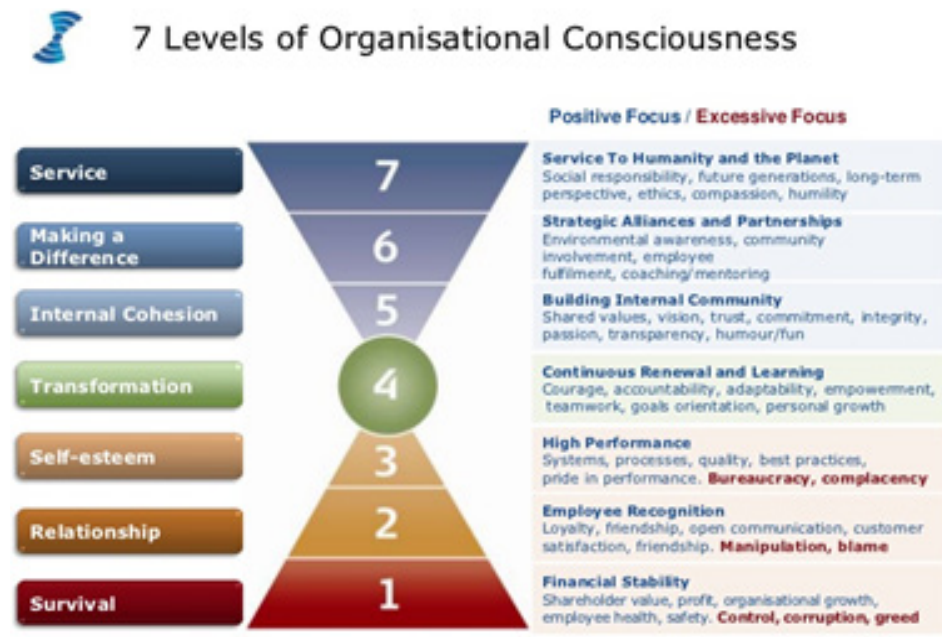

Figure 1. The seven levels of personal and organizational awareness Source: Barrett Values Center, 1997.

Sen (2000) mentions that the poverty is seen such as deprivation of basic needs. Moreover, privation that causes premature death, malnutrition, illiteracy and other disabilities, according to the author, poverty affects not only the developing countries but also in affluent as Europeans who suffer from the fall in jobs that generates "social exclusion", with loss of freedom, autonomy, self-confidence, physical and mental health. Thus we see the influence of the pyramid of Maslow's needs and the seven levels of Barrett.

\section{DATA AND METHOLOGY}

This study aimed to carry out analyzes of the Ibero-American region (AIBER) the main theme Biodiversity - Natural and Social Capital, and verify the degree of relationship between the variables of interest.

The data in this analysis included, the 21 countries of the Ibero-American region (AIBER), it is shown in Table 1. These data are represented by synthetic and analytical indicators most relevant to allow analysis and conclusions on the theme Biodiversity, Natural and Social Capital, and assist those involved in ORIBER Project - Observatory RIBER.

The Ibero-American Millennium Project - RIBER aims to promote prospective studies in Iberoamerica through a community with skills, concepts, methods and prospective practices for analyzing and exchanging information about the different countries of the region; and contribute to the learning collective regional actors to develop skills in prospective, providing references of best 
practices in the region and the world as a whole.

Table 1. Countries of Ibero-American

\begin{tabular}{|ccc|}
\hline \hline Argentina & Dominican Republic & Panama \\
Bolivia & Ecuador & Paraguay \\
Brazil & El Salvador & Peru \\
Chile & Guatemala & Portugal \\
Columbia & Honduras & Spain \\
Costa Rica & Mexico & Uruguay \\
Cuba & Nicaragua & Venezuela \\
\hline
\end{tabular}

This research topic submitted a total of 33 (thirty-three) variables, three categorical - Country, Country code and REGION; and thirty quantitative variables. However, this study only will use the 9 variables identified as high explanatory power, as shown in Table 2.

Table 2. The variables of interest for this work

\begin{tabular}{|c|c|c|}
\hline Variable & Description & Type \\
\hline $\begin{array}{l}\text { Opp (Opportunity) } \\
\text { Nominal-Quantitative }\end{array}$ & $\begin{array}{l}\text { Measures the degree to which a country's citizens have personal } \\
\text { rights and freedoms. Opportunity also includes the degree to which } \\
\text { advanced forms of education are accessible to those in a country } \\
\text { who wish to further their knowledge and skills, creating the } \\
\text { potential for wide-ranging personal opportunity. }\end{array}$ & Capital Social \\
\hline $\begin{array}{l}\text { Waterw (Water } \\
\text { withdrawals as a } \\
\text { percent of resources) } \\
\text { Nominal-Quantitative }\end{array}$ & $\begin{array}{l}\text { The ratio of total withdrawals to total renewable supply in a given } \\
\text { area. Water available to agricultural, domestic, and industrial. }\end{array}$ & $\begin{array}{l}\text { Capital } \\
\text { Natural }\end{array}$ \\
\hline $\begin{array}{l}\text { Immi (Tolerance for } \\
\text { immigrants) } \\
\text { Percentage- } \\
\text { Quantitative }\end{array}$ & $\begin{array}{l}\text { The percentage of respondents answering yes to the question, "Is } \\
\text { the city or area where you live a good place or not a good place to } \\
\text { live for immigrants from other countries?" }\end{array}$ & Capital Social \\
\hline $\begin{array}{ll}\text { Relig } & \text { (Religious } \\
\text { tolerance) } & \text { Nominal- } \\
\text { Quantitative } & \end{array}$ & $\begin{array}{l}\text { A measure of } 13 \text { types of religious hostility by private individuals, } \\
\text { organizations or groups in society, including religion-related } \\
\text { armed conflict or terrorism, mob or sectarian violence, harassment }\end{array}$ & Capital Social \\
\hline
\end{tabular}

${ }^{1}$ Note: As stated, Cuba that was originally classified as a country in the Caribbean region, has been integrated in AIBER for analysis and results of this work. 


\begin{tabular}{|l|l|c|}
\hline & $\begin{array}{l}\text { over attire for religious reasons or other religion-related intimation } \\
\text { or abuse. }\end{array}$ & \\
\hline $\begin{array}{l}\text { Hdi (Human } \\
\text { Development Index) } \\
\text { Nominal-Quantitative }\end{array}$ & $\begin{array}{l}\text { Measures of average achievement in key dimensions of human } \\
\text { development: a long and healthy life, being knowledgeable and } \\
\text { have a decent standard of living. }\end{array}$ & Capital Social \\
\hline $\begin{array}{l}\text { Gov (Govemance) } \\
\text { Nominal-Quantitative }\end{array}$ & $\begin{array}{l}\text { Consists of the traditions and institutions by which authority in a } \\
\text { country is exercised. }\end{array}$ & Capital Social \\
\hline $\begin{array}{l}\text { Epi (Environmental } \\
\text { Performance Index) } \\
\text { Nominal-Quantitative }\end{array}$ & $\begin{array}{l}\text { Measures of average achievement of Environmental Health: Child } \\
\text { Mortality (probability of dying between a child's first and fifth } \\
\text { Ecosystem Vitality: Wastewater Treatment, Agricultural } \\
\text { Subsidies, Pesticide Regulation, Change in Forest Cover, Coastal }\end{array}$ & Natural \\
Shelf Fishing Pressure, Fish Stocks and Biodiversity and Habitat. & \\
\hline $\begin{array}{l}\text { Hpi (Happy Planet } \\
\text { Index) Nominal- } \\
\text { Quantitative }\end{array}$ & $\begin{array}{l}\text { The HPI measures what matters: the extent to which countries } \\
\text { deliver long, happy, sustainable lives for the people that live in } \\
\text { them. The Index uses global data on life expectancy, experienced } \\
\text { well-being and Ecological Footprint to calculate this. }\end{array}$ & Capital Social \\
\hline $\begin{array}{l}\text { Democ (Democracy } \\
\text { Index) Nominal- } \\
\text { Quantitative }\end{array}$ & $\begin{array}{l}\text { The Democracy Index is based on five categories: electoral } \\
\text { process and pluralism; civil liberties; the functioning of } \\
\text { government; political participation; and political culture. }\end{array}$ & Capital Social \\
\hline
\end{tabular}

Source: Made by the authors, based on GPS Guide, World Bank, UNDP, WRI, SPI and Yale informations.

The data were compiled by the World Bank. The statistical software used in this study was Minitab and through him the following analyzes were performed: grouping by similarity (Dendrogram), Principal Component Analysis (dimensionality reduction) and One-way ANOVA (analysis of variance).

\section{DATA ANALYSIS}

The groups were conducted to demonstrate the degree of relationship of the variables presented in Table 2. The best packing arrangement was 4 clusters, using the method and complete the distance measurement by the Manhattan system.

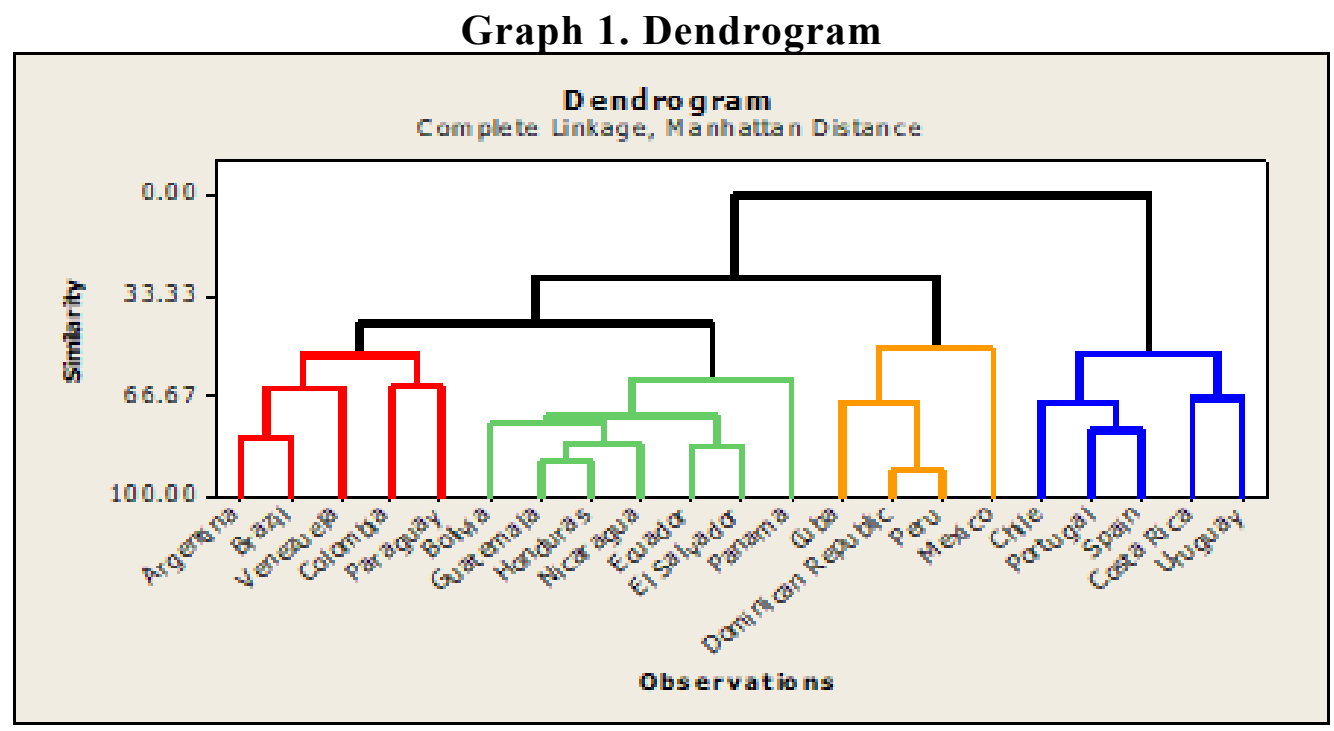

Source: by authors, 2016 .

Therefore, with the defined groups and set each country as a member of their respective cluster, was performed the One-way ANOVA analysis to understand the variability between groups and assist in the classification of countries. A second ANOVA was generated and ordered from lowest to highest average, according to Table 3 . 
Table 3. Clusters of the average order

\begin{tabular}{ccccc}
\hline Level & N & Mean & StDev & Color Cluster \\
\hline \hline 1 & 7 & 54,346 & 10,462 & Green \\
2 & 4 & 66,377 & 4,008 & Orange \\
3 & 5 & 67,532 & 9,720 & Red \\
4 & 5 & 79,098 & 7,065 & Blue \\
\hline
\end{tabular}

Source: by authors, 2016

Thus, to analyze which variables has been high explanatory power, an analysis of the main components was made, according to Hair (2009) the goal to this analysis is to find a way to condense the information contained in various original variables into a smaller set of statistical variables with loss minimum information.

Graph 2. Principal components analysis

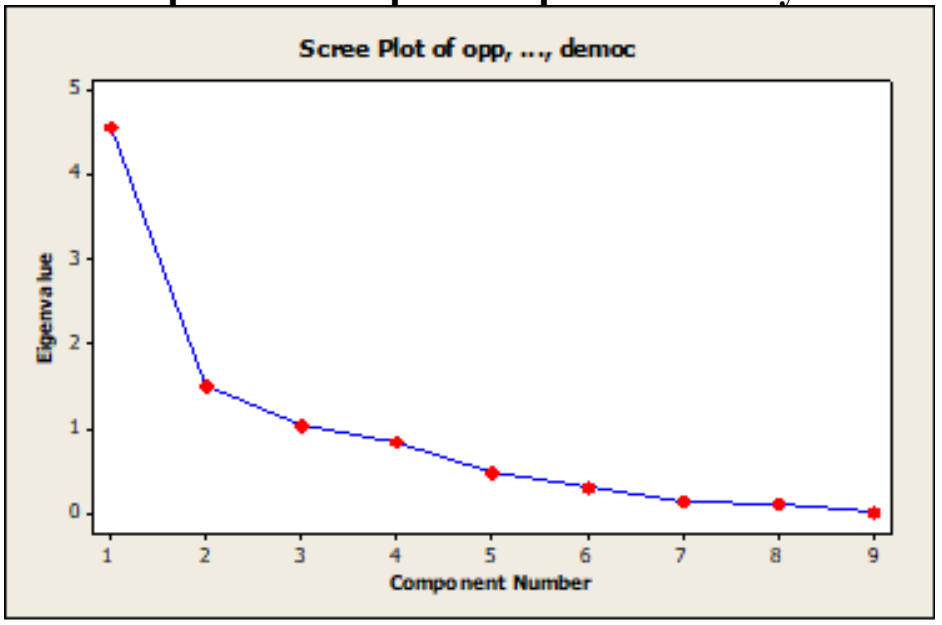

Source: by authors, 2016.

In the analysis, we see that the PC1 components, PC2, PC3 and PC4, explain $88.1 \%$ of the variability of the data. Las Casas and Guevara (2010) show that by convention components must only be considered with a contribution equal to or greater than 1. The AIBER countries were ranked in descending order by PC1 values, which led the ranking:

Table 4. Classification of the Ibero-American countries - AIBER

\begin{tabular}{|c|c|c|}
\hline COUNTRIES ORD & RANKING & PCl-NORMALIZADA \\
\hline Spain & HIGH & 100.000 \\
\hline Portugal & HIGH & 93.662 \\
\hline Chile & HIGH & 77.400 \\
\hline Uruguay & HIGH & 75.803 \\
\hline Costa Rica & HIGH & 62.569 \\
\hline Argentina & MEDIUM & 55.208 \\
\hline Brazil & MEDIUM & 49.868 \\
\hline Panama & MEDIUM & 39.209 \\
\hline Mexico & MEDIUM & 36.565 \\
\hline
\end{tabular}




\begin{tabular}{|c|c|c|}
\hline Peru & MEDIUM & 34.660 \\
\hline Dominican Republic & MEDIUM & 33.901 \\
\hline Colombia & MEDIUM & 31.318 \\
\hline Paraguay & LOW & 30.862 \\
\hline Bolivia & LOW & 20.620 \\
\hline El Salvador & LOW & 19.783 \\
\hline Ecuador & LOW & 18.680 \\
\hline Venezuela & LOW & 18.599 \\
\hline Cuba & LOW & 9.896 \\
\hline Nicaragua & LOW & 2.564 \\
\hline Honduras & LOW & 0.045 \\
\hline Guatemala & LOW & 0.000 \\
\hline
\end{tabular}

Source: by authors, 2016.

We can say that due to closeness of the results in the ANOVA analysis, grouped to the countries of the clusters 2 and 3 in the table 4, it shows as "MEDIUM" on the ranking scale of countries AIBER. Figure 2 shows the map with the classification countries.

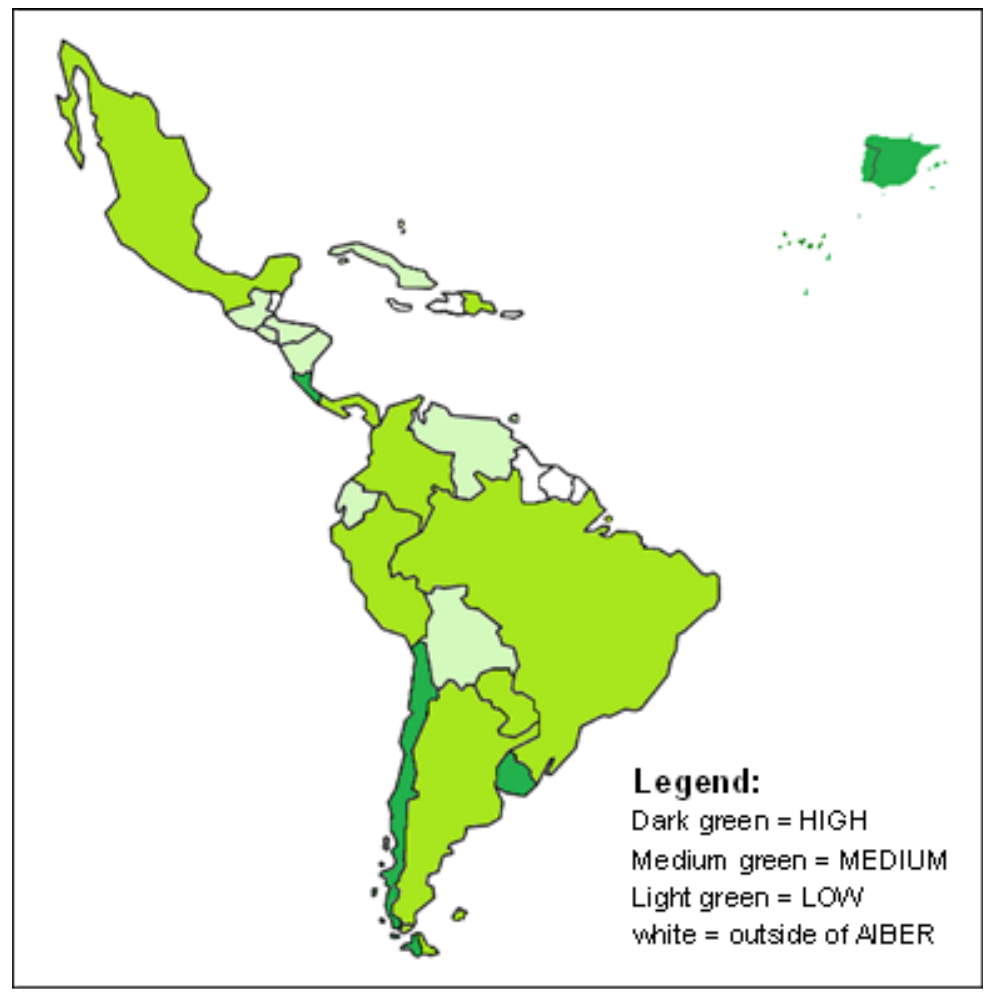

Figure 1. Classification map of the countries of Ibero-America - AIBER Source: by authors, 2016.

In the analysis of the Ibero-American region, Spain and Portugal are classified in the top of the list (dark green), with the best results. On the other hand, when considering only the Latin American countries was positive especially Chile, Uruguay and Costa Rica. Seven countries were in the middle range of the table (medium green), notably Argentina, Brazil, Panama and Mexico. And in the bottom of the list (light green), with the lowest performances were highlighted, Guatemala, Honduras, Nicaragua and Cuba. 


\section{CONCLUSIONS}

This study was carried out analyzes of the Ibero-American region (AIBER) Biodiversity thematic area - Natural and Social Capital, to check the degree of relationship between the variables of interest. Using an integrative view, it was considered here the theme of biodiversity widely, covering not only natural resources, but also considering the social and economic agents in this analysis.

Therefore, It is observed that as the pyramid of Maslow's needs and the seven Barrett's levels of consciousness, so that the individual has the capacity to engage in issues related to the environment, health of the planet and decreased injustice in the world, it needs first have their basic needs gotten.

With the results of analyzes, the countries of the region were classified according to their ability to manage and promote actions to take care of your assets from natural capital and social capital. Thus, countries such as Spain and Portugal made the top of list with the best results, and followed by them, are Chile, Uruguay and Costa Rica. Moreover, seven countries are in the middle range of the table, especially in Argentina, Brazil, Panama and Mexico. And at the bottom of the list with the lowest performances were highlighted, Guatemala, Honduras, Nicaragua and Cuba.

Sen (2000) points out that poverty is seen as deprivation of basic needs, these needs will vary according to the level of poverty in each country and how it is in the pyramid of Maslow's needs and range of awareness levels Barrett. Besides that, countries such as Portugal and Spain, are in a better row position of Chile, Uruguay and Costa Rica, they are countries with a higher HDI, namely that already have well-resolved way dimensions related to: Health (long and healthy life ; life expectancy), education (years of schooling for adults and children) and income (standard of living measured by Gross National Income - GNI).

In conclusion, we can said that Guatemala, Honduras, Nicaragua and Cuba appear at lower levels need to care more care of these most basic questions. It was observed that the 9 most important variables for biodiversity only 2 "epi" and "waterw" are related to natural capital; while the other seven variables "opp", "IMMI" "Relig" "hdi" "gov", "hpi" and "democ", are more focused on the capital. So, this can strengthen the theories of Maslow and Barrett, however, fade the placement of Sachs and Brown that the natural and social capital must go together in equal importance so that we can ensure biodiversity on the planet, as the authors state, a change in social paradigm it is necessary, we need to put the B4.0 plan in place as well as demystify the idea that, as stated Sachs, "the market is a short-sighted and invisible nature of both the social, as the ecological". 


\section{REFERENCES}

Brown, L. R., \& Plano, B.. 4.0: mobilização para salvar a civilização.São Paulo: New Conten, 2009.

Sachs, I. Barricadas de ontem, campos de futuro. estudos avançados, 2010, 24(68), 25-38.

Cordeiro, L. L. (org.). O comportamento humano na empresa. Rio de Janeiro: FGV, 1997, pp. 337366.

Democracy https://www.eiu.com/democracy2014

EPI http://epi.yale.edubvc

Frando, J. L. de Andrade. O conceito de biodiversidade e a história da biologia da conservação: da preservação da wilderness à conservação da biodiversidade. História (São Paulo), 2013, 32(2), 21-48. http://www.scielo.br/pdf/his/v32n2/a03v32n2

Governance http://info.worldbank.org/governance/wgi/index.aspx

Hair, Joseph F. et al. Análise multivariada de dados. Bookman Editora, 2009.

Hampton, D. R. Administração contemporânea: teoria, prática e casos. São Paulo: McGraw-Hill, 1992.

HDI Human Developmnt INDEX http://hdr.undp.org/en/content/human-development-index-hdi

HPI http://www.happyplanetindex.org/about

Huitt, W. G. Maslow's hierarchy of needs, obtida via internet, 1998. http://chiron.valdosta.edu/whuitt/ col/regsys/maslow.htm.

Las Casas, Alexandre Luzzi; Guevara, Arnoldo José de Hoyos. Pesquisa de Marketing. São Paulo: Atlas, 2010.

Lewis, Michael. Wilderness and Conservation Science. In: Lewis, Michael (edited by). American Wilderness: A New History. New York: Oxford University Press, 2007, p. 205-261.

Marques, L. G. A., Pessoa, C., \& Santos, M. R. D. M. C. O valor econômico da Biodiversidade e os países megadiversos: os caminhos para a inovação tecnológica, 2014, 41.

Mayr, E. O desenvolvimento do pensamento biológico: diversidade, evolução e herança. Ed. UnB, 1998.

Maslow, A. H. Uma teoria da motivação humana. In: BALCÃO, Y, 1975.

Meine, Curt; Soué, Michael; Noss, Reed F. A mission-driven discipline: the growth of conservation biology. Conservation Biology, 2006, v. 20, p. 631-651.

Reimann, E. A questão ambiental no Brasil do futuro. http://www.ffn-brasil.org.br/novo/PDF-ex/ ContribuicoesLiberais/Artigo_PL_Eduardo_Reimann.pdf

Sarkar, Sahotra. Defining "Biodiversity”, Assessing Biodiversity. The Monist, 2002, v. 85, n. 1, p. 131-155.

Semenik, R. J.; Bamossy, G. J.. Princípios do marketing: uma perspectiva global. São Paulo: Makron 
Books, 1995.

Sen, A., \& Mendes, R. D.. Desenvolvimento como liberdade. São Paulo: Companhia das Letras, 2000.

Schaller, George B. A Naturalist and Other Beasts. Tales from a life in the field. San Francisco: Sierra Club Books, 2007.

Scharmer, O.. Liderar a partir do future que emerge: evolução do sistema econômicoegocênrico para o ecocêntrico. Rio de Janeiro: Editora Elsevier, 2014

Social Progress Imperative. http://www.socialprogressimperative.org/global-index/methodology

Sustentáveis, C.. Guia GPS-Gestão Pública Sustentável. São Paulo, 2014. http://www.pucsp.br/posgraduacao/mestrado-e-doutorado/gps-gestao-publica-sustentavel

UEBT launched the 8th Biodiversity Barometer on 26 May $2016 \mathrm{http}$ :/ethicalbiotrade.org/biodiversitybarometer/

Water Stress Country http://www.wri.org/resources/charts-graphs/water-stress-country

Wilson, Edward O . (Org.). Biodiversidade. Rio de Janeiro: Nova Fronteira, 1997.

World Bank. Indicators | Data - The World Bank. Retrieved from: http://data.worldbank.org/indicator 